\title{
高応答電磁弁を使った空気圧シリンダの高精度位置決め*
}

\author{
小山 紀**, 原田 正一** \\ 井田良 博***, 吉田 寿****

\section{High Accuracy Positioning of Pneumatic Cylinder Using High Response Solenoid Valve}

\author{
Osamu OYAMA, Masakazu HARADA \\ Yosihiro IDA, Hisasi YOSIDA
}

The high accuracy position servo system of pneumatic cylinder is already reported by using a diaphragmtype electro-pneumatic converter. In this paper, a novel simple high accuracy position servo system are shown by using high response solenoid valves. The actuating part consists only of two valves and a cylinder. The valves open or close by a pulsating signal and charge the air to the cylinder or discharge from the cylinder directly. The pulse time duration and interval change with position of piston and this is not same as the conventional PWM method. To realize high accuracy piston displacement, the interval becomes as short as $0.005 \mathrm{~s}$ when the piston approaches near by the desired point.

The characteristics of this servo system are given by using a system model, and the relationship between stability of the piston displacement and valve opening duration can be shown theoretically. The single rod-type cylinder with $40 \mathrm{~mm}$ bore and $100 \mathrm{~mm}$ stroke is tested experimentally. As a result of repeated positioning test, it was shown that the piston keeps moving slightly at the desired point but it is able to position within $0.01 \mathrm{~mm}$ to the point.

\section{1. 緒}

空気式アクチュエータは、長い間高精度制御はでき ないものと考えられてきたが，著者らは既に膜形電空 変換器を使って高精度位置決めを実現している ${ }^{1)}$.ま た最近，高精度制御の試みがさかんに行われるように なり, 空気式アクチュエータを高度な自動機に利用す る道が開かれてきている。しかしこれらの多くは比例 制御弁と組合わせて行われているため, 軽量安価とい う特性が損なわれる可能性が指摘される。また比例制 御弁自体もまだ開発過程にある．本報では小型の電磁 弁を使った位置サーボ機構を提案する．電磁弁を使っ た位置決めや速度制御機構に花房ら ${ }^{2)}$ や則次 ${ }^{3) 4}$ のもの がある。ここでは空気圧シリンダへの給気および排気

*昭和 63 年 10 月 31 日 原稿受付
$* *$ 明治大学
***横河電機
$* * * *$ 東芝
(所在地 $\uparrow 214$ 川崎市多摩区東三田 $1-1-1$ )

を高応答の電磁弁で直接制御する方式で、良好な位置 決め性能が示されたので報告する。これは 2 個の 2 ボート弁を使ったもので（5ボート弁を使えば 1 個で よい), きわめて簡便な構造となっている.

\section{2. 実験装置および理論}

高応答電磁弁を使った位置サーボ機構の概略図を Fig. 1に示す. 空気圧シリンダの一方には一定圧力 $P C$ を加えて, 単動式にしている.ピストンは伸長時には $\mathrm{A}$ 弁を, 収縮時にはBの弁を開くことにより, 目標 位置に位置決めされる.このとき弁は可変周期の短い パルスにより駆動されている.一周期で一回の弁開お よび弁閉が行われるが，A，Bの弁開および弁閉時間 Tao, TboとTac, Tbcはそれぞれ次のようにする.

$$
\begin{aligned}
& y<=Y_{d} \text { の時 } \quad T a o=K v a\left(Y_{d}-y\right) \\
& T a c=\text { 一定 } \\
& y>Y_{d} \text { の 時 } \quad T b o=K v b\left(y-Y_{d}\right) \\
& T b c=\text { 一定 }
\end{aligned}
$$

ここで $Y_{d}, y$ はそれぞれ目標位置およびサンプル時位 置である.Tac, Tbcは $10 \mathrm{~ms}$ を超えない程度で, 位置の 


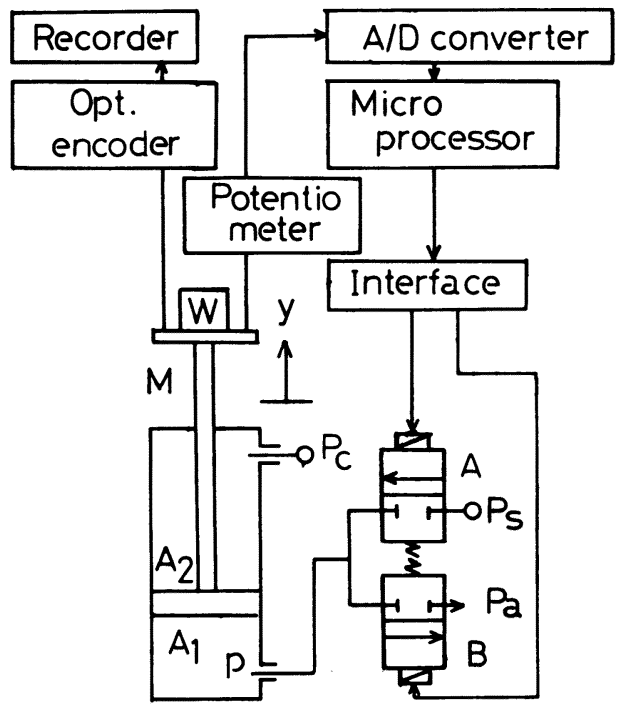

Fig. 1 Experimental pneumatic servo system

サンプルはこの間におこなう，Tao,Tboが100msを超 えるときは $100 \mathrm{~ms}$ 与える。しがってこの方式では 通常のパルス幅変調方式 (PWM方式) と異なりピスト ン位置によりサンプル周期が変わり，目標位置近傍で 最も短くなる，位置決め場所で可能な限り位置の検査 の頻度を高くして高精度化を計ると同時に，弁通過の 空気流量が多く必要な時には弁開放を十分長いパルス で行い，弁動作が確実に行われるようにしたものであ る、比例制御弁の弁開度の効果を弁開時間に置換えて いるともいえるが，比例制御と同様の効果があること を理論により確認する。

この系を状態変数を使ったモデルで表せば，Aの弁 の開放時は次のように近似できる.

$\dot{x}=\boldsymbol{A} x+\boldsymbol{B}[\mathrm{Ps} \mathrm{Pc} \mathrm{F} \mathrm{W}]^{\mathrm{T}}$

$\mathrm{y}=\left[\begin{array}{lll}1 & 0 & 0\end{array}\right] \boldsymbol{x}$

ここで

$\begin{aligned} \boldsymbol{A} & =\left[\begin{array}{ccc}0 & 1 & 0 \\ 0 & -\frac{D}{M} & \frac{A_{1}}{M} \\ 0 & 0 & -\frac{1}{R C}\end{array}\right] \\ \boldsymbol{B} & =\left[\begin{array}{cccc}0 & 0 & 0 & 0 \\ 0 & -\frac{A_{2}}{M} & -\frac{\operatorname{SGN}(\dot{y})}{M} & -\frac{1}{M} \\ \frac{1}{R C} & 0 & 0 & 0\end{array}\right]\end{aligned}$

$C=\frac{V_{0}+A_{1} y}{1.4(p+P a)}$
ただし $A_{1}, A_{2}$ はピストン受圧面積， $D$ は粘性摩擦係 数, $F$ はクーロン摩擦力, $M$ は可動部質量, $W$ は荷重 である．Psは亀磁弁の供給圧でBの弁開放時は零とす る. $P a$ は大気圧, $P c$ はロッド側一定圧, pはへッド側 圧力, $R$ は実験から求める弁の抵抗であり $V_{0}$ は配管の 容積である、したがってCはシリンダと配管による キャパシタンスである， $R$ とCは压力とピストン位置 により変わるため時変システムとなるが, それぞれサ ンプル時の值を用いる.つぎに弁閉鎖時は次のように なる.

$$
\begin{aligned}
& \dot{x}=\boldsymbol{A} x+\boldsymbol{B}\left[\begin{array}{llll}
p & P c & F & W
\end{array}\right]^{\mathrm{T}} \\
& y=\left[\begin{array}{ll}
1 & 0
\end{array}\right] \boldsymbol{x} \\
& \text { ここで } \\
& \boldsymbol{A}=\left[\begin{array}{cc}
0 & 1 \\
0 & -\frac{D}{M}
\end{array}\right]
\end{aligned}
$$

$$
\boldsymbol{B}=\left[\begin{array}{cccc}
0 & 0 & 0 & 0 \\
\frac{A_{1}}{M} & \frac{A_{2}}{M} & -\frac{\mathrm{SGN}(\dot{y})}{M} & -\frac{1}{M}
\end{array}\right]
$$

これらの式では弁開あるいは弁閉中のピストン移動に よる圧力変化は, 時間が短いので移動距離も少ないと 考え無視している。サンプル間隔が一定であればこれ らの式を離散化して応答を計算できるが，前述のよう に位置により異なるので推移行列 $\exp (A t)$ を使って弁 動作毎に計算した。すなわち弁開時間はサンプル時の $y に よ り(1)$ 式から求められるので, 次のサンプルまで のxの推移が計算できる、これを繰返すことによりピ ストン移動をシミュレートした。また弁動作のむだ時 間や弁開時間に対する通過量の非直線性などは, 弁の 特性に関する実験結果を使ってTao,Tboを補正して 計算に用いた。

\section{3、实㕋および結果}

弁を通過する流量波形は完全なステップ状にならな いが, 各弁開時間および圧力差毎の通過量から,この 間の実効抵抗 $R$ の值を求める. 供試電磁弁の特性を Fig. 2に示す.横軸に弁開時間, 緃軸にそのときの通過 空気量を示す.ただし一回のみの動作での空気量を測 定することは困難なので, おなじ幅のパルスで綝返し て開閉させて, その結果から弁開時間あたりの平均通 過空気量を求めた。この電磁弁はポペット弁を使用し た試作品で毎秒300回程度までの開閉動作が可能な,か なり応答の速いものであり高応答電磁弁と称す。 $0.3 \mathrm{~ms}$ 程度の弁開時間で動作を開始して, 以後の通過 量は弁開時間の増加にほほ比例している，ただし弁開 


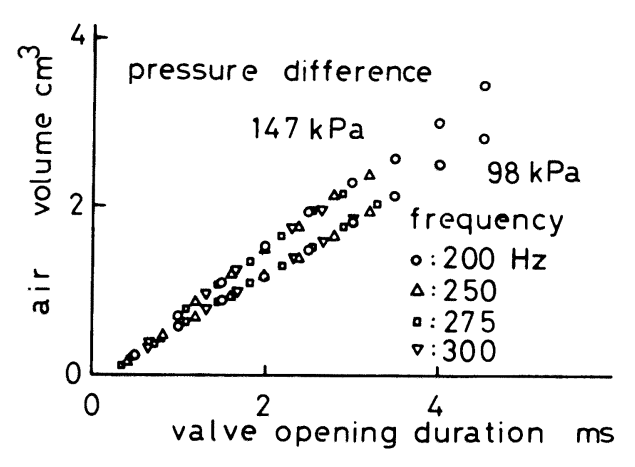

Fig. 2 Relation between valve opening duration and air volume through the valve

時間の非常に短いときの通過量は開閉毎にばらつくも のと思われる。シリンダ入口で熱線流速計により観測 された弁動作のむだ時間は約1.5msであった。

使用したシリンダは内径 $40 \mathrm{~mm}$, 行程 $100 \mathrm{~mm}$ で上下方向 に動作させた。シールを交換してやや低摩摖化を計っ たが，その実測結果は市販の同型のものとあまり変わ

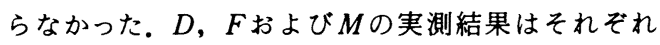
$1362 \mathrm{Ns} / \mathrm{m}, 0.49 \mathrm{~N}$ よび $0.4 \mathrm{~kg}$ であった。後述の理由で $P s, P c$ を比較的低い圧力として,このピストンを約50 $\mathrm{mm}$ の場所に位置決めしたときの計算結果をFig. 3に示 す。まず荷重なし，したがってピストン自重および測 定部重量のみが加わる場合の例を示す. 初期条件とし てピストンはスロークエンド $(y=0 \mathrm{~mm})$ にあり,この ときのpは大気圧であるものとした．約 $1 \mathrm{~s}$ 程度で位置 決めされるが, 弁開時間を決める $K v$ が小さいときは大 きくオーバシュートして，整定までに時間がかかる． これは $K v$ が小さいと均り合点付近で弁通過流量が制 限される結果, シリンダ内圧力が応答遅れを起こすた めである. $K v$ を $3 \mathrm{~s} / \mathrm{m}$ 以上とすると行き過ぎ量は 1.5

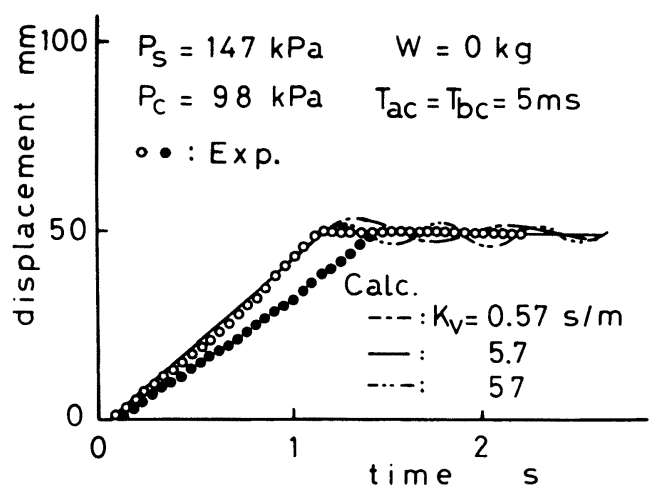

Fig. 3 Step response with no load $\mathrm{mm}$ 程度になる. $K v$ をさらに変えても行き過ぎ量は, シ ミュレーションではこれより小さくはならなかった。 $K v=5.7 \mathrm{~s} / \mathrm{m}$ は実際の実験を行ったときの条件である が，実際の方が安定的であり，白丸に示す実験結果で はオーバシュートはほとんど観測されない。これは停 止直前で摩擦力が移動中より大きくなるためと考えら れる. 他のところは両者は比較的よく一致している. $K v$ をさらに大きくすると, 応答は再び振動的になり もっと大きくすると発散する．理論的にオーバシュー トが防げないのは，この方式が流量制御方式であり， 他の流量形比例制御弁を使ったシステムと同様に，シ リンダ内圧力の応答遅れが避けられないためである. しかしこの問題は流量と,これにより変化するシリン ダ内圧力との間に伝達関数があるために発生するもの であるから，高次の状態量をフィードバックさせて， いわゆる極配置を行うことで解決できると考えている. $K v$ を変えても計算では立ち上がり速度が変わらない のは，ピストン移動による圧力変化を無視したためと 思われる，黒丸はPWM方式でほほ同様のパラメー夕 を用いて位置決めを行ったものである，PWM方式で の最適化等についての検討はしていないため一概には 判断できないが，本制御方式の方が整定が速いことが わかった。

供給圧力が低いためあまり大きな荷重は与えられな いが，質量荷重 $2 \mathrm{~kg}$ をえたときの結果をFig. 4 に示 す.この場合位置決めには約 $2 \mathrm{~s}$ 程度を要したが，その 他は荷重のない場合とほほ同様の結果となった。これ らの実験結果によると立ち上がり速度はピストン位置 によらず一定となり，粘性摩擦力により制限されてい るのがわかる。したがってさらに速く位置決めしたり， 重荷重を扱うにはより高い圧力を与えなくてはならな 々.

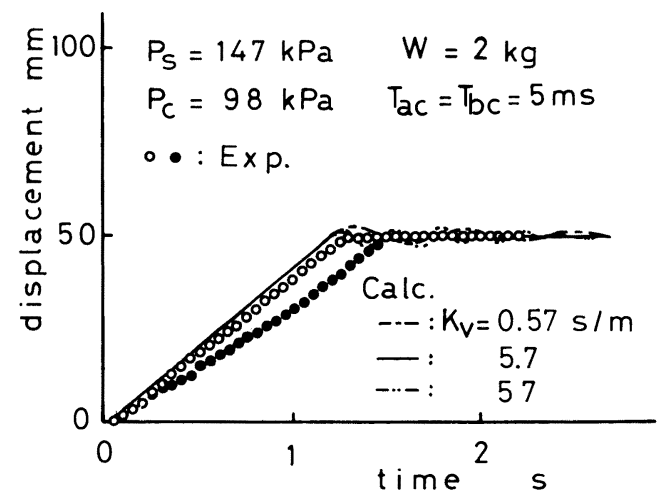

Fig. 4 Step response with $2 \mathrm{~kg}$ load 


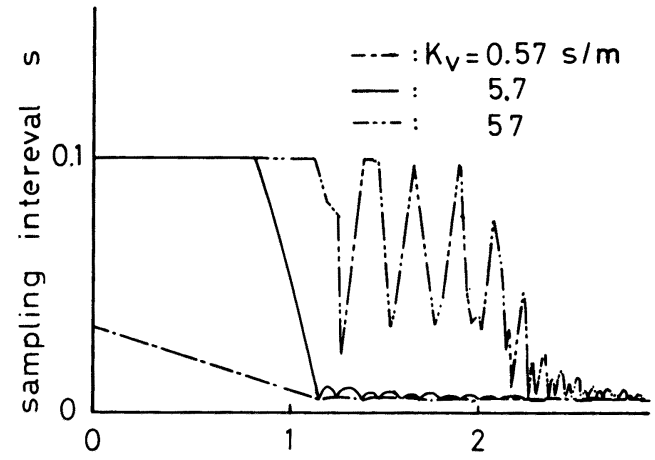

Fig. 5 Sample time interval changes

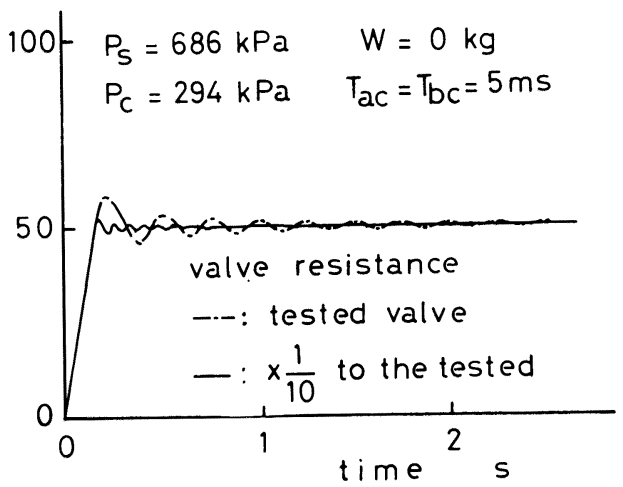

Fig. 6 Step response when high pressure exited

Fig. 5にFig. 4の場合のサンプリング周期を計算結 果により示す。場所および条件により変わり, 位置決 め場所でほほ一定值（この場合では0.005s）になる.

Fig. 6には $P s$ を $686 \mathrm{kPa}, P c$ を $294 \mathrm{kPa}$ とそれぞれ高 くしたシミュレーション結果を示す。一点鎖線で示す $K v=0.57 \mathrm{~s} / \mathrm{m}$ 程度では整定が遅いがこれ以上大きく しても改善されない。これはピストン移動が速くなる ため, $K v$ を大きくするとサンプル遅れが問題となるた めである. 弁の有効断面積が10倍位大きくできれば, 図中の実線に示すように $0.2 \mathrm{~s}$ 程度の高速位置決めが可 能となる. 高速でかつ大流量の弁の開発が望まれる.

供試弁は有効断面積が小さいので低圧力で動作させ て，同一場所に繰返し位置決めしてその精度を調べた。 制御回路は 8 ビットCPUによるフルソフトウエア サーボとした。位置のフィードバックにはポテンショ

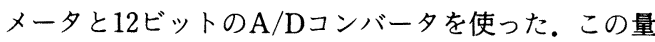
子化量は $0.015 \mathrm{~mm}$ である.ただし測定は光学式りニアエ

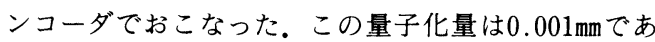
り, 累積誤差はピストン全行程で $0.003 \mathrm{~mm}$ 以下となって いる.

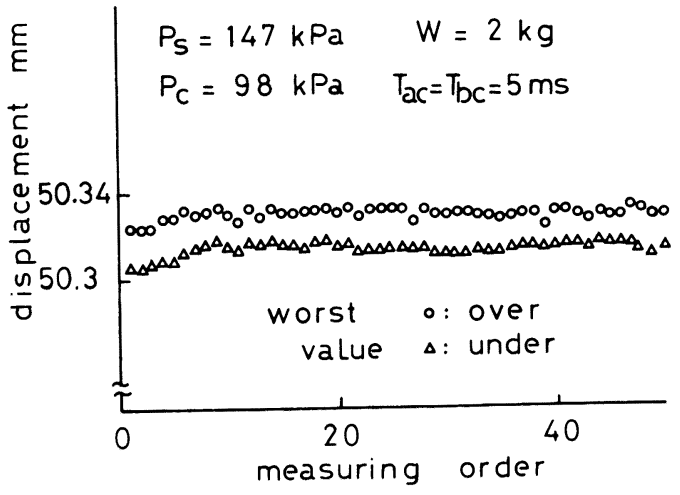

Fig. 7 Worst (most over and under) position value under positioning

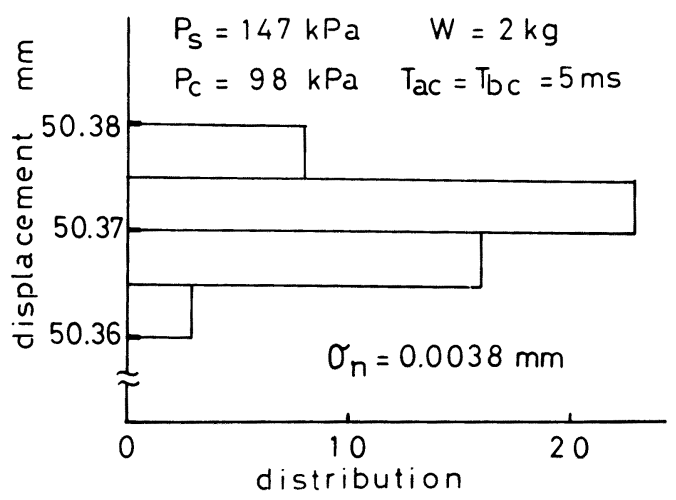

Fig. 8 Distribution of position

本機構は位置決めが完了した後はすべての弁は閉じ たままとなり，シリンダへの給排気はおこなわれない 筈であるが，弁が時々動作してピストンが細かく動く． この動きを小さくすることもひとつの課題である.

Fig. 7に位置決めしたままで数分間放置して，この間 測定された最悪值（最も目標位置にたいして行過ぎた 位置と手前の位置）を示す，測定は50回行い左から測 定順に並べて示している，位置決め後もピストンは約 $0.02 \mathrm{~mm}$ の範囲で動いていることになる，この範囲は， フィードバック系の量子化量にほほ等しい.

Fig. 8に同一場所に50回繰返し位置決めをしたとき に，測定された位置のヒストグラムの例を示す。ただ し, 前述のように位置決め後もピストンは微動するた めこの間の最頻值を使う. 分布の形は完全な正規分布 とはならないが, 中央位置付近に高い頻度で分布して いる.目標位置に対する位置決め精度は,フィードバッ ク系の量子化量の $0.015 \mathrm{~mm}$ 程度と考えられるが, 以後で は位置決めの精度の評価は, 主として絽返し精度を考 
慮してエンコーダで測定された位置の標準偏差でおこ なう。この例の場合位置の標準偏差は $0.0038 \mathrm{~mm}$ となる. この值はポテンショメータと A/Dコンバータによる 量子化量よりも小さい.これはコンバータの量子化卜 リガ点付近に集中して位置決めがおこなわれているた めと考えられる。

目標位置に数分間位置決めをしておき，その間に $50 \mathrm{~ms}$ 毎に位置を記録し, 最覀値と最頻値および標準偏 差などを整理したものをTable 1に示す. 各同一の条 件毎にサーボ機構に十分な休止時間（数時間あるいは 数日）をおいて，5回づつの測定を行って再現性を調 べた。その結果各位置決めの間のピストン位置の標準 偏差は数ミクロン程度であり, かなりの時間を経た後 でもその位置の平均値あるいは最頻値のずれは最大 $0.02 \mathrm{~mm}$ 程度であった。ただし室温度等の一定化は行っ ていない.なるべく同じ条件になるようにしたが，そ れでも完全に同じでないことを考慮すると,このサー ボ機構はかなりの再現性精度を持っていると思われる。

荷重がある場合とない場合では, 平均位㯰が約 0.01 mm程度異なっている。このサーボ機構は積分機能を本 来的に内蔵しているため（圧力差で釣り合うため静的 バネを内蔵しないのでこうなる), 理論的には位置に対 しては定常偏差なく追従しこれが特長の一つでもある が，実際はこのように偏差を生じた，Pcが完全に一定 ではないか, 荷重により停止直前の速度が変わってく るため, ピストンシールの弾性変形やクリープの影響 が現れてくるのかもしれない.

弁開時間は先に示されたように，ある範囲では比例
ゲインのような働きをするから定常偏差をなくすため に，積分動作の機能を弁の開放時間にもたせることが 可能な筈である。このような観点から現在積分動作を 加えた系統的実験を行っており，まだ件数は少ないが 良好な結果が得られている。

Table 2 に $300 \mathrm{~Hz}$ の周期のPWM方式で同様に位置 決めした場合の結果を示す。最悪値の範囲や標準偏差 の值はさきの場合よりやや大きくなる，さらに荷重に たいする位置の平均值あるいは最頻値の変化もやや大 きくなり, 今回提案した方式の有用性が確認できた。

このように電磁弁を使った位置サーボ系でも，位置 決め後にピストンが微動する欠点があるものの, 繰返 し精度は比例制御方式と比べ劣ることはなく, 構造の 簡便さなどの点でむしろ優位であるともいえる，現在 このピストンが位置決め後に時々微動する原因につい て調べているが，もし空気の漏れかノイズの影響によ る量子化誤差等が原因であれば解決できるものと思わ れる。

\section{4. 結}

2 個の電磁弁を使ってシリンダの給排気を，直接パ ルス状に制限する方式の位置サーボ機構を試作した。 3 ポートあるいは 5 ポートの弁を使えば 1 個ですむこ とになり，これ以上は考えられない程の簡便な構造を している，また系全体でも簡便な構成となることを目 的とし， 8 ビットCPUを使ったボードコンピュータ や，位置センサにポテンショメータを採用した．弁開 時間を調節することにより，通過流量を制御する方式

Table 1 Results of positioning accuracy

\begin{tabular}{|cc|c|c|c|c|}
\hline \multicolumn{2}{|c|}{$\begin{array}{c}\text { Ps }=147 \mathrm{kPa} \\
\text { worst value } \\
\text { max }\end{array}$} & deviation & mean & median & $\begin{array}{c}\text { most } \\
\text { frequent }\end{array}$ \\
\hline \multicolumn{6}{|c|}{$\mathrm{W}=0 \mathrm{~kg}$} \\
\hline 50.377 & 50.370 & 0.0018 & 50.375 & 50.374 & 50.376 \\
50.391 & 50.380 & 0.0028 & 50.387 & 50.386 & 50.387 \\
50.389 & 50.380 & 0.0021 & 50.384 & 50.385 & 50.385 \\
50.402 & 50.391 & 0.0022 & 50.397 & 50.397 & 50.397 \\
50.399 & 50.386 & 0.0026 & 50.394 & 50.393 & 50.395 \\
\hline \multicolumn{7}{|c|}{$\mathrm{W}=2 \mathrm{~kg}$} & \\
\hline 50.380 & 50.357 & 0.0067 & 50.368 & 50.369 & 50.377 \\
50.390 & 50.351 & 0.0091 & 50.372 & 50.371 & 50.375 \\
50.377 & 50.339 & 0.0080 & 50.359 & 50.359 & 50.357 \\
50.377 & 50.351 & 0.0086 & 50.366 & 50.364 & 50.372 \\
50.377 & 50.351 & 0.0086 & 50.366 & 50.364 & 50.372 \\
\hline
\end{tabular}


Table 2 Results of positioning accuracy

\begin{tabular}{|cc|c|c|c|c|}
\hline \multicolumn{2}{|c|}{$\begin{array}{c}\text { Ps=147kPa } \\
\text { worst value } \\
\text { max }\end{array}$} & deviation & mean & median & $\begin{array}{c}\text { most } \\
\text { frequent }\end{array}$ \\
\hline \multicolumn{6}{|c|}{$\mathrm{W}=0 \mathrm{~kg}$} \\
\hline 50.414 & 50.401 & 0.0036 & 50.409 & 50.408 & 50.410 \\
50.409 & 50.392 & 0.0039 & 50.405 & 50.401 & 50.406 \\
50.414 & 50.401 & 0.0039 & 50.410 & 50.408 & 50.412 \\
50.412 & 50.403 & 0.0029 & 50.407 & 50.408 & 50.405 \\
50.412 & 50.405 & 0.0022 & 50.410 & 50.409 & 50.410 \\
\hline \multicolumn{7}{|c|}{$\mathrm{W}=2 \mathrm{~kg}$} & & \\
\hline 50.324 & 50.302 & 0.0060 & 50.314 & 50.313 & 50.318 \\
50.333 & 50.303 & 0.0072 & 50.321 & 50.318 & 50.322 \\
50.327 & 50.298 & 0.0072 & 50.312 & 50.313 & 50.317 \\
50.340 & 50.310 & 0.0070 & 50.326 & 50.325 & 50.332 \\
50.324 & 50.299 & 0.0052 & 50.317 & 50.312 & 50.321 \\
\hline
\end{tabular}

を提案してまず理論によりその有用性を確認した。そ の結果現在所有する電磁弁では, あまり高い圧力の領 域では整定時間の点で使えないことも理論式を使った シミュレーションによりわかった。したがって比較的 圧力を低くして位置决めをおこなった，定点に繰返し 位置决めした結果，その標準偏差は0.0038mm程度とな り非常に高い繰返し精度をもっているのが示された。 これは高応答電磁弁が極めて短いパルス幅で動作し, 細かい流量調整が可能であったためと考えられる。こ のときセンサの量子化量も問題となった。現在ではよ り高い分解能をもつセンサが使えるが，ポテンショ メータも価格の点で捨てがたい.

以上で示したように，まだいくつかの解決すべき問 題点が残されているが，このように簡便な機構でも精 度の点では従来の比例制御方式によるものと同等以上 であった．空気式の長所は負荷への柔軟性のみが強調 されているが，このような簡便な制御入力にも柔軟に 応答する良さが確認できた。さらに大流量の扱える電
磁弁が開発されれば，他に提案されている種々のディ ジタル方式を含めて, 一気に実用化が進むものと思う. なお電磁弁およびシリンダの機材は，黒田精工㑣よ り供与を受けた。厚くお礼を述べる。

\section{考支献}

1) 小山ほか：：電気空気圧サーボ方式によるピスト ンシリンダの位置決め, 油圧と空気圧, 16 巻-4 号, 275/280 (1985)

2 ) 花房ほか：空気圧シリンダのパルス駆動に関する 研究, 油圧と空気圧, 7 巻一 3 号, 336/341 (1976)

3 ) 則次 : パルス幅変調方式による電気・空気圧サー ボ機構の研究, 計測自動制御学会論文集, 20 巻 -8 号, 754/761 (1984)

4 ）則次：オンオフ電磁弁を用いた空気圧モータの速 度制御, 昭和 59 年秋期油空圧講演会講演論文集, $1 / 4, \quad$ (1984) 